\title{
An Analytical Study On Role Of Trade Association For Women Entrepreneurship And Their Capacity Building
}

\author{
Shazia Sharafat \\ Women's Studies \\ University of Karachi \\ Nasreen Aslam Shah \\ Social Work \& Women's Studies \\ University of Karachi
}

\begin{abstract}
The chambers and associations in Pakistan are mainly represented by men. Meantime the representation of women entrepreneurs is also gaining momentum. Women entrepreneurs have formed chambers in the country to explore potentials and create platform for resolving issues arising during undertaking businesses. The study identified that women have potential and are working hard. Yet they are at takeoff position to get success in expanding the business set-up and getting recognition. The government has brought some changes in the rules for establishing trade organization and allowed formation of separate chambers for women considering their participation in different businesses. It is observed that some efforts have been made by women members under the umbrella of Federation of Pakistan Chambers of Commerce and Industry (FPCCI) to organize conferences and roundtables to promote and explore business skill of women. The FPCCI, as the apex trade body of the country, organized national and international exhibitions in which they have given equal opportunities to women as men. However, women entrepreneurs are still facing problems due to lack of business knowledge while operating business.
\end{abstract}

Keywords: Business Associations, Chambers of Commerce and Industry, Women Entrepreneurs.

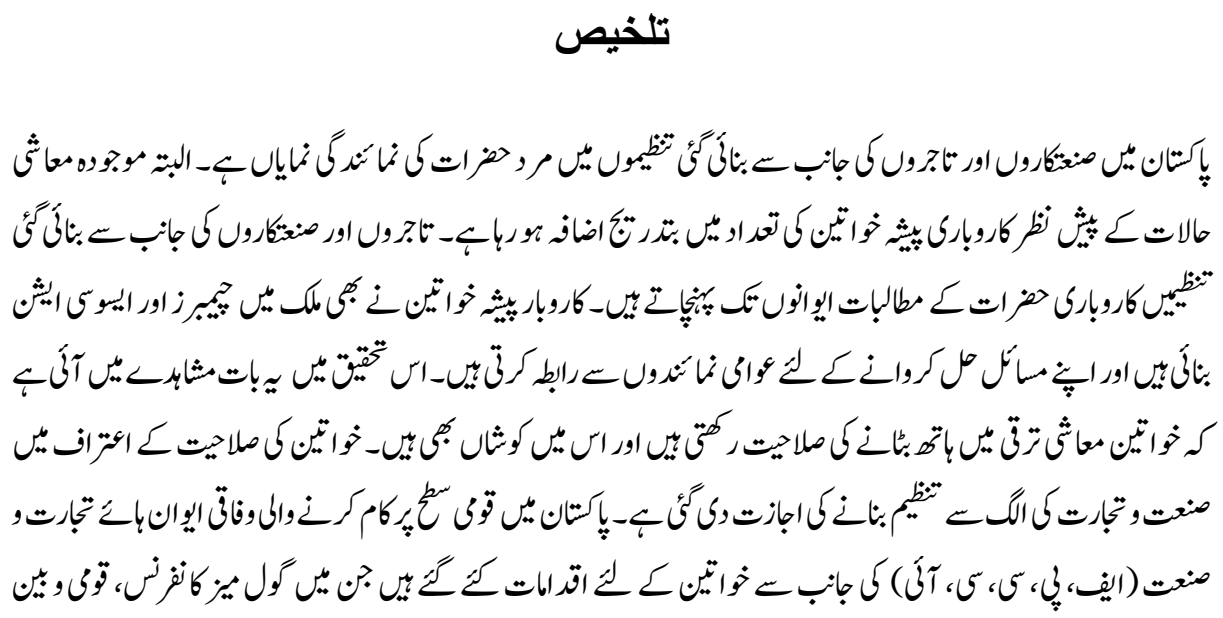




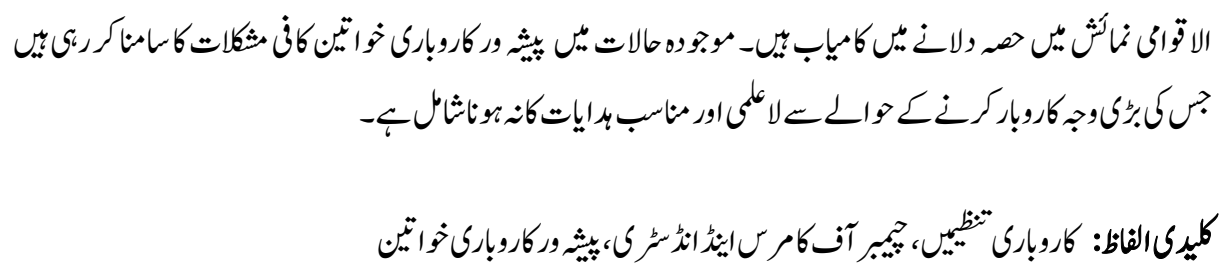

\section{Introduction}

The history tells women's role restricted to family and bound to perform their duties being a mother or homemaker. Men's role has been defined as bread earner and guardian of house. In short, a man brings goods while a woman converts for consumption purpose (Rani, 1996). (Agalgatti \& Bhooshan, 2008) this traditional concept however changed with urbanization that increased the role of women. It changed the family structure with more importance to a woman due to education and participation in financial and monetary affairs of a house. In some instances women replaced men for managing household. Mechanization and automation are the major boost for women, which created opportunities for them, as such reduced the physical work that were meant for men. Smith (2013) stated that association of businessmen or traders can be defined as collective body of individuals having common interests in specific industry or sector of an economy.

Singla (2009-2010) showed that the trade and association conduct surveys and make publications for benefit of their members to understand the market needs. Simply, the functions of trade and associations can be defined as: to raise issues against government policies that are against businesses; compiling updated information and other resources and subsequently disseminate their members; imparting training to members for meeting challenges; and organize trade fairs to showcase their products. Busquets (2006) viewed that trade bodies have not only formed by major manufacturing sectors but the Small and Medium Enterprises (SMEs) have also set up their associations to show their presence in local and international businesses. Raghavan (1995) noticed that the free market economy and establishment of World Trade Organization (WTO) prompted the business community to form group at regional level for the improvement of trade. Such groups can be identified such as North American Free Trade Agreement (NAFTA), Association of Southeast Asian Nation (ASEAN) and South Asian Association for Regional Cooperation (SAARC.) As per available record of modern world, chambers were formally formed in Jersey and New York in 1767 that followed thousands of chambers and industries around the globe (Bennett, 2011). The list of trade bodies has expanded in short span of time and as per international chamber of commerce it has 12,000 registered members.

In Pakistan, Trade Organization Ordinance (TOO) was passed through a presidential order on December 31, 2006 in which it is permitted to create separate women's chambers and commerce and industry. Moreover, after the formation of women chambers, separate laws were drafted into the Trade Organizations Act (TOA), 2013, which are similar to men. 
According to Trade Organizations Rule (TOR) 2013, "women chamber" means a chamber of commerce and industry to represent women entrepreneurs as defined in clause (c) of subsection (2) of section 3; and "woman entrepreneur" means: (Ministry of Commerce, 2013)

(i) A sole proprietorship where the proprietor is a female; or

(ii) A partnership where the majority partners are female; or

(iii) An association of any kind where majority of its persons are female; or

(iv) A company where majority shares are held by females.

At present about nine women chambers have been established but those are also failed to make any pressure group for resolving issues of businesswomen. There must be reasons that women representing these chambers are under influence of male business leaders especially in their election for the top slot.

The modern world has recognized the importance of women and their role in economic growth. The contribution of women in developed nations has increased manifold. However, women are struggling in developing and under developed economies to show their presence. In recent past the government of Pakistan amended many laws to give protection to women at workplace and increase opportunities in mainstream business for women entrepreneurs. The private sector is also playing its role by giving due importance to women empowerment. Chambers and association play a pivotal role in resolving business issues of same interest group.

However, there are reasons to conduct the research because the trade bodies are not so far much successful in empowering women in activities related to trade and industry besides identifying causes of failure in cases of selected group of women and also analyze success in similar manner. Major objectives in the research are to make women fully aware about formation of chambers and associations and their role in business growth. In fact, to find such women entrepreneurs who have established separate women chambers across the country. Women should get benefit of such platform where they could discuss business issues or trade related problems with business community in order to resolve it professionally. The united groups of women in associations could advocate or oppose policies and legislations of their economic interest to the government. The collected data of women entrepreneurs must be circulated to statistical departments for adding women population in business sector of the country. It will not only create national businesswomen database but also show the improved strength of female-labour force.

The FPCCI being the national chamber has power to influence the policies of the government related to the economic activities of the country besides promoting gender equality for the advancement of trade and business. Recently, the business leaders have chosen women entrepreneurs as their managing committee members for having influence to empower the women related business activities. The apex body also conducted research on all the sectors of the economy for identifying the issues but it is unfortunate that despite tall claims of the FPCCI there was not a single working paper available 
related to women business activities (FPCCI, 2014). On the other hand, the Karachi Chamber of Commerce and Industry (KCCI), the largest chamber in the country and representing the metropolitan city that contributes about $68 \%$ of the revenue to the national exchequer (Waleed, 2015). There are nine women chambers have been established so far but those are also failed to form any pressure group for resolving issues of businesswomen. There must be reason that women representing these chambers are under influence of male business leaders especially in their election for the top slot.

\section{Woman Entrepreneur}

Scholars are unable to make a suitable definition of 'entrepreneur', which can explain the meaning of this word. The term for women is defined as a woman who is capable of controlling business setup and family affairs at the same time.

\section{Trade Bodies and Chambers of Commerce and Industry}

An association is a group of businessmen and businesswomen to protect the common interests of its members. Chambers of commerce and industry are formed at district to national levels. A member of a trade body gets benefits for enhanced business activity. Investopedia (2014) defines: "Chamber of commerce plays an important role in local municipalities in promoting business activity and representing chamber members. At least at the local level, chamber of commerce members often meet to discuss and attempt to shape policy that relates to the business and overall economic environment. Members also receive the distinction of being a preferred local vendor, as well as listing on various municipal websites and literature."

\section{Research Questions}

1. The basic research question of the study is: Are trade bodies helpful to women entrepreneurs when there are specific provisions in prevailing trade laws for women. How they get facilitated or availed such opportunities? To what extent trade bodies assisting businesswomen?

2. The second research question of the study is: changing economic conditions are leading women towards entrepreneurship. In many studies it has been highlighted that due to less education or confinement of women also a reason for working in a house, in traditional societies of Pakistan.

\section{Objectives of the Research}

- To explore potential women entrepreneurs with having skills to establish chambers and associations.

- To aware women entrepreneurs about the power of chambers and associations. 
- To suggest relevant statistical bodies to circulate relative field statistics to all stakeholders.

- To empower women entrepreneurs for considering, supporting or opposing legislative or other government measures effective for an economic interest of women entrepreneurs.

\section{Hypotheses}

1. Role of trade associations is helpful in promoting business of women.

2. The changing economic conditions lead women towards entrepreneurship.

\section{Review of Literature}

Historic researches have highlighted that rising women entrepreneurship is emerged from gender awareness and increasing pressure of women's movements. The enhanced women participation in economic activities led to creation of business chambers across the globe. The creation of business association resulted in importance of women in policy making. The experiences of the research findings are that there is prime importance to include women at different fora and bring at par with men (Stange, 2011).

It is also observed that the informal economic sectors are also major drivers in rising women entrepreneurship. The small scale, micro and SMEs business are one of those. The past literary work revealed that women have close connection with informal sector and lower income. To estimates about 50 percent of women are self-employed in the developing economies (Bahramitash \& Espahani, 2016). International Finance Corporation (2004) estimates of MSMEs owned by women provide a similar picture and suggest that 40 percent women have owned out of 270 million of business units around the world. It is identified that most of women were engaged in the informal sector mainly associated with home based activities.

The research paper of OECD (2012) mentioned that the importance of business chambers has attracted women to have association in order function as an independent entity. The association with chambers attracts women because of linkages of those trade bodies with the government in negotiating the demands.

However, the women entrepreneurs are not successful so far from taking much assistance from business associations. The trade bodies are providing assistance to women entrepreneurs in displaying their products at fairs and exhibitions. Some of the serious work to empower women has come from public sector side, which is assisting women in micro and cottage industries and supporting them in their capacity building. (Commonwealth, 2002). 
Entrepreneurial researches said that women have achieved the current status of their presence in economic growth after an untiring struggle. The contribution of women in developed nations has increased manifold. Their struggle in developing and least developed economies to show their presence is still continue.

Meanwhile, Grob (1992) stated that history has given importance to a woman as wife, mother and child-rearing. The history has also restricted women going from outside and must obey whatever their male relatives say. This makes women as submissive gender of that time. Women were not independent to their decisions.

Similarly, Simon de Beauvoir in her book 'The Second Sex' explains women as dependent to men not only by slavery but by all means and both the sexes were never attained rights on equal basis. In present world women are remained not able to take decision individually and independently despite the fact that the situation has started to change. Woman does not share the equality in legal rights to men in fact, in job markets men are highly paid than women (Duiker and Spielvogel, 2010).

Many of feminist researches has revealed that the great achievements in the history mainly attributed to men because of their authority on writing the history and women contribution was mostly neglected. In some cases women were given fair treatment but they were mostly confined to ignorable position (Pushkareva, 1997). Women were supposed to do household work besides working in farms and undertaking other manufacturing activities, which left no spare time in their lives. Men, in contrast, meant for war games and their almost all the activities related to it (Ember, 2003).

Forestell (2014) identified that the nineteenth century gave women rights to emerge in entire social life from politics to legal reforms, which enabled them to recognize themselves internationally. Kahle (2005) demonstrated that it is bitter reality of the history that women of eighteenth and nineteenth centuries had no civil rights under the law and they were treated as end of their rights after marriage and even they were not allowed to declare will or raise voice for their wages. Partly end of nineteenth century and start of twentieth century highlighted the women's rights which also included the participation of women in trade unions for raising their voices for demanding rights at workplaces (Goodwin \& Jasper, 2009).

In times of renaissance, many writers came up with women movements in order to attain equality and equity in the lives at all segments of life. Likewise, Mary Wollstonecraft published the first feminist treaties in the UK. 'A vindication on the rights of women in 1792 , she supported the social and moral equality of the sexes. In the US leading political figures also supported the campaign of women voting rights. A Vindication on the Rights of Women in 1792 termed that 'Declaration of the Rights of Women' as a wok which 
could be called feminist. First wave of feminism can be referred to period of nineteenth and early twentieth century in the UK and the US which mainly stressed upon the rights of women's suffrage.

Meanwhile, feminists in the year 1960 had started demanding women rights which period is known for beginning of second wave of feminist movement. The movement primarily focused on color, disability and transgendered people. Women had also been mobilized in opposition to the military government of General Augusto Pinochet 1970. In Chile, similar to other Latin American women campaigned for eradicating abuses, poverty, and sexism (Banaszak, 2006).

The third wave of women's movement has been attributed to present time. The movement that was started in late twentieth century has been believed to be revived. Rory Dicker and Alison Piepmeier were professors of women's studies, suggested that the third wave of feminism should involve women into politics, capitalism and information technology. Third wavers termed the movement for achievements and called failures of second wave (Rory Dicker and Alison Piepmeier cited in Richard, 2008).

Research findings have highlighted that the women of industrialization had been viewed in both ways in terms of gainers and losers. The employment of women has been viewed that industrialization had opened wider job opportunities and liberation (Verdon, 2002). In contrast, another view emerged on account of pessimism, that it had reduced opportunities for women work due to high demand of physical power, and leaving women to low-paid work and dependency on men.

Whereas, the country's chambers of commerce and other development agencies such as United Nation Development Programme (UNDP), International Chambers of Commerce and Industry (ICCI) have launched many projects to strengthen businesswomen through arranging workshops; conferences in order to enhance marketing skills; exporting capacities for small business oriented women entrepreneurs. UNDP and United Arab Emirates (UAE) have conducted a study in Gulf States where they focus on awareness about roles; functions; and powers of chambers; in such a way that women entrepreneurs can use maximum opportunities in business chambers; associations; trade bodies. The organizations are guiding potential women entrepreneurs for establishing their own separate business chambers (UNDP, 2003).

The OECD had arranged conference on "Women Entrepreneurship in SMEs" in 1997, where different scholars and businesspersons have discussed about exploring ways to develop network of women entrepreneurs; technology diffusion; access to markets and encourage women to participate in business organization. Through all cooperation's of business institutions trade and business related data must disseminate on regular basis to 
women (OECD, 1998). This dissertation will find out that to which extent measures have picked up momentum for advancement of women in business and finance.

However, Mumba (2014) research study on "Empowering Women Enterprises in Africa: Investigating Information Access \& Use of Information \& Communication Technologies by women-owned enterprises in Zambia" identified that women entrepreneurs are lagging from business education and Information Communication Technologies (ICTs) to build strong business and business network. He believed that government should facilitate them or other stakeholders of the business community for their success because they have potential to run business independently. But due to lack of business knowledge or ICTs they are not growing at faster pace. He said in his research that women entrepreneurs should learn all such business knowledge from formal sources. It is envisaged that if businesswomen join trade bodies or any other formal business organization then business information and ICTs handling skills may become familiar and with the passage of time they may become professional businesswomen.

The research of Makombe (2006) on "Women Entrepreneurship Development \& Empowerment in Tanzania: The Case of SIDO/UNIDO-Supported women microenterprises in the food processing sector" unveiled that Small Industries Development Organization (SIDO) and United Nations International Development Organization (UNIDO) are helping towards economic empowerment of businesswomen and explained factors that there should be liberty for using their own income; should contribute in household expenses; should have powers to own assets; should be a part of trade associations; should participate in trade fairs and must be aware about their legal rights. The findings identified that entrepreneurial trainings or business education sessions for women are fruitful in development of entrepreneurial activities. Women presence in trade associations and trade fairs are indications of economic empowerment. It gives impression that they need permanent assistance or shelter of advisory of any independent business/trade body in further development of business.

It is identified that women entrepreneurs are facing many problems such as financial issues; lack of management skills and so on but instead of this "There are some legal/administrative factors including access to policy maker, high amount of taxes and interest; bureaucracy and red tapes and overall legal regulatory environment." There must be reforms in business laws, incentives, relief or ease in policies or taxes, microfinance should be available on easy interests for women entrepreneurs in order to bear the cost of doing business. In this regard, there must be a separate platform for women entrepreneurs for raising their voices. The study further added that human capital having zero knowledge has nothing do with the production (Wube, 2010). So, it is important that there must be trained labour force for producing goods and services. It is worthy that production must be innovative or different at feasible cost as there is high competition in domestic and international markets. 
Many scholars argued that women's position mainly benefited capitalism and capitalists (McGuire, 1994). The capitalists having benefits by creating huge job market for women at lower wages. Marsh (2008) cited Natasha Walter - the new feminism (1998) who has criticized postmodern and radical feminism and presented a different view of contemporary feminism. She believes that common cause exists for women to unite to achieve equality. According to her, many British women think feminism as convincing men are the biggest oppressors. Pakistani rural women groups working in agriculture economy and urban women working in private sector as cheap labourers. The Express Tribune (2015) news article stated that according to ILO estimates women earnings about $38.5 \%$ less than men in such sectors. It is oppression by the capitalists; even not providing any opportunities for growth and development of women. It is observed that women do not have any other option besides start some home-based works which need extra capital to start their own at small levels in order to get rid of working on low wages.

\section{Challenges to Women Entrepreneurs}

Dr. Vural (2011) mentioned that the rising population of educated women indicates the more women entrepreneurs. According to the data of Pakistan Education Statistics 20102011 , boys' enrolment in degree education was at $49.2 \%$ and girls' enrolment was at $50.58 \%$ (Bhargava et al, 2007). However, socio-economy with the overlay of Islam, women are facing challenges while participating economic activities. Presently, the prime challenges for women included cash flows, lack of business management skills, unaware with government regulations (Hagan, 1998).

Lack of access finance to start a business is the major hurdle for women entrepreneurs. A research conducted by the International Finance Corporation (IFC) in the Middle East and North African countries (MENA) revealed that women entrepreneurs at small levels start their business from personal resources (IFC, 2004). Obtaining loans from formal banking channels is one of the milestones for women, as majority of them are not aware about the banking finance. Another study unveiled that Pakistani women also lack control over capital, land and business premises (World Bank, 2012).

These reasons limit women to the lower level investment and remained under capitalized system besides no urge to avail loan schemes of government regarding financing on easy conditions. In this state they are not able to reach their growth potential (Economist Publication, 2007). It is also observed that women entrepreneurs face discrimination from bankers. Further many women due to non-availability of collateral, they do not approach banks (Nirjar, 2011).

Roomi identified "Challenges faced by women entrepreneurs, included: access to capital/finance; lack of business management skills; government policy; registration; utility connections; tax harassment; lack of technical skills; purchase of raw material; availability of market; access to information technology." Roomi also identified: "Gender 
related challenges faced by women in Pakistan included: spatial mobility; choice of business; support of family; networking and trust building; acceptance of women's authority; credibility (employees, customers, and suppliers); fear of failure; and time distribution between family and business (Roomi cited in Guy, 2008)."

\section{Private Sector Fostering Role of Women Entrepreneurship in Pakistan}

\section{Directorate General of Trade Organizations (DGTO)}

DGTO is an authority works under Ministry of Commerce, Government of Pakistan. It issues license to trade organizations/chambers of commerce/ associations and regulates trade policies. DGTO (2013) ensures that trade bodies must be supportive for all business sectors at all levels. In Trade Organization Act 2013 they explained the criteria for the formation of separate women chambers in the country.

\section{Role of FPCCI in Development of Women Entrepreneurship}

Lodhi (2015) highlighted that FPCCI is actively participating in advocacy for women entrepreneurship development and facilitation for their inclusion in trade and industry especially in making part of delegations for participating local and international exhibitions. In 2001, FPCCI launched initiatives for women entrepreneurs to bring them in mainstream business and established a standing committee for promotion of women entrepreneurs. In 2015 realizing the businesswomen prime importance in the economic sectors, FPCCI established "Central Committee on Women Entrepreneurs." Each women chamber has voting right for the election of FPCCI as well as for a reserved seat of woman vice president slot at FPCCI.

\section{List of Women Vice Presidents of FPCCI}

The trade rule and act has reserved a seat for a woman vice president in FPCCI and the following are included: Dr. Shehla Javed Akram (2011), Begum Salma Ahmed (2012), Mrs. Rukhsana Jehangir (2013), Ms. Naima Ansari (2014), Ms. Fehmida Kauser Jamali (2015) and Ms. Sajida Zulfiqar (2016).

\section{FPCCI Best Lady Exporter Gold Medal Award}

Providing recognition to women entrepreneurs in order to encourage women owned businesses; the FPCCI has instituted a "Best Lady Exporter Gold Medal Award", (The Express Tribune, 2010) which is awarded to a female entrepreneur who has shown more exports during the year export awards. 


\section{Women Chamber of Commerce and Industry in Pakistan}

Center for International Private Enterprise (CIPE) research report unveiled that all women chambers representing the four provinces of Pakistan, are continuously working to encourage women entrepreneurs and facilitate in business operations where required through negotiations for bank loans and in developing contacts with various government departments. These chambers organize business orientation programs, workshops, and lectures, for the guidance of women entrepreneurs and also work to enhance quality consciousness of women-owned enterprises (CIPE cited in Nadgrodkiewicz, 2011).

\begin{tabular}{|c|c|c|c|}
\hline \multicolumn{4}{|c|}{ Women Chambers in Pakistan } \\
\hline Women Chamber's & $\begin{array}{c}\text { Year of } \\
\text { Creation }\end{array}$ & $\begin{array}{l}\text { Founder } \\
\text { President }\end{array}$ & President 2015 \\
\hline $\begin{array}{l}\text { Women Chamber of } \\
\text { Commerce \&Industry } \\
\text { (Lahore Division) }\end{array}$ & 2008 & Dr. Shehla Javed & Ms. Farah Jahangir \\
\hline $\begin{array}{l}\text { Islamabad Women Chamber } \\
\text { of Commerce \& Industry }\end{array}$ & 2008 & $\begin{array}{l}\text { Ms. Samina } \\
\text { Fazil }\end{array}$ & Ms. Zakia Hashmi \\
\hline $\begin{array}{l}\text { Women Chamber of } \\
\text { Commerce \& Industry, } \\
\text { Mardan }\end{array}$ & ------ & ------ & Ms. Sabina \\
\hline $\begin{array}{l}\text { Women Chamber of } \\
\text { Commerce \& Industry, } \\
\text { Peshawar }\end{array}$ & 2012 & $\begin{array}{l}\text { Ms. Sajida } \\
\text { Zulfiqar }\end{array}$ & $\begin{array}{l}\text { Mrs. Fitrath Ilyas } \\
\text { Bilour }\end{array}$ \\
\hline $\begin{array}{l}\text { Women Chamber of } \\
\text { Commerce and Industry, } \\
\text { Multan Division }\end{array}$ & 2008 & Ms. Masooma & Ms. Humera Batool \\
\hline $\begin{array}{l}\text { Women Chamber of } \\
\text { Commerce \&Industry } \\
\text { Quetta, Baluchistan }\end{array}$ & ---- & ----- & $\begin{array}{l}\text { Mrs. Kulsoom } \\
\text { Parveen }\end{array}$ \\
\hline $\begin{array}{l}\text { Women Chamber of } \\
\text { Commerce \&Industry } \\
\text { Quetta, Division }\end{array}$ & 2012 & $\begin{array}{l}\text { Ms. Fehmida } \\
\text { Jamali }\end{array}$ & Ms. Aryana Khan \\
\hline $\begin{array}{l}\text { Women Chamber of } \\
\text { Commerce \& Industry } \\
\text { Bahawalpur Division }\end{array}$ & 2014 & $\begin{array}{l}\text { Ms. Elahi } \\
\text { Rehmat Raj }\end{array}$ & $\begin{array}{l}\text { Ms. Shireen Arshad } \\
\text { Khan }\end{array}$ \\
\hline $\begin{array}{l}\text { Karachi Women Chamber } \\
\text { (KWCCI) District East }\end{array}$ & 2015 & Ms. Saeeda Bano & $\begin{array}{l}\text { Ms. Syeda Saeeda } \\
\text { Bano }\end{array}$ \\
\hline $\begin{array}{l}\text { Women Chamber of } \\
\text { Commerce \& industry } \\
\text { South Zone, Karachi }\end{array}$ & 2015 & $\begin{array}{l}\text { Ms. Farida } \\
\text { Qureshi }\end{array}$ & Ms. Farida Qureshi \\
\hline
\end{tabular}

(Source: Data compiled from FPCCI Membership Booklet 2015) 


\section{Methodology}

The self-administered questionnaire has been designed for obtaining inputs from the respondents to analyze the research problem. This research has conducted by both quantitative and qualitative methods in order to get powerful results from the research questions. A detailed questionnaire was designed for a selected group accordingly for evolving knowledge, that how or to what extent trade bodies are providing assistance to women entrepreneurs. Individual interviews were planned where only interviewer or interviewee will interact with each other where full control over time and confidentiality. Trade associations provided the members list of women entrepreneurs with complete information. All interviews have been conducted by the researcher by visiting their business outlets, residence and in trade associations. Whereas, in some of cases, a researcher even have approval letter from departments proof of conducting research would not be enough to get the information. In such situation, references of chambers' officials and associations were required to conduct interview with sample of the research. The sample of women entrepreneurs has been divided carefully according to the size of trade associations: The research has obtained detailed interviews of 200 women entrepreneurs from five big business associations of Pakistan. The associations namely Federation of Pakistan Chambers of Commerce and Industry (FPCCI), Karachi Chambers of Commerce and Industry (KCCI), Site Association, Korangi Association of Trade and Industry (KATI), and Pakistan Software Houses Association (P@SHA). The study identified the state of businesswomen in trade bodies. And all these associations have representations of businesswomen at national and international levels. The obtained data further analyze through Statistical Package for the Social Sciences (SPSS) in which variables have been tested through chi-square test of independence. 
Table: 1

Testing independence of 'women chambers promoting women in private sector' and 'success of business'

\begin{tabular}{|c|c|c|c|c|c|}
\hline \multicolumn{2}{|c|}{ Women chambers promoting women in private sector * is business successful cross tabulation } \\
\hline \multicolumn{2}{|c|}{} & \multicolumn{1}{|c|}{ Is business successful } & \multirow{2}{*}{ Total } \\
\hline \multirow{2}{*}{$\begin{array}{c}\text { Women } \\
\text { chambers } \\
\text { promoting } \\
\text { women in } \\
\text { private sector }\end{array}$} & $\begin{array}{c}\text { (Yes) Organize meetings with } \\
\text { other business persons }\end{array}$ & Count & 23 & 3 & 26 \\
\cline { 2 - 5 } & $\begin{array}{c}\text { (Yes) Organize exhibitions/ } \\
\text { conferences/workshops/ seminars }\end{array}$ & Count & 106 & 28 & 134 \\
\cline { 2 - 5 } & $\begin{array}{c}\text { (No) Trade bodies working for } \\
\text { specific strata }\end{array}$ & Count & 28 & 1 & 29 \\
\cline { 2 - 5 } & $\begin{array}{c}\text { (No) Not helpful in resolving } \\
\text { financial matters }\end{array}$ & Count & 3 & 8 & 11 \\
\hline \multicolumn{2}{|c|}{ Total } & $\mathbf{1 6 0}$ & $\mathbf{4 0}$ & $\mathbf{2 0 0}$ \\
\hline
\end{tabular}

\section{Interpretation}

$\mathrm{H}_{\mathrm{o}}$ : women chambers are not promoting women in private sector due to the reason not successful in business.

$\mathrm{H}_{1}$ : Women chambers promoting women in private sector as business are successful.

Pearson chi-square value $=25.310^{\mathrm{a}}$

$\mathrm{df}=3$

$\mathrm{p}=0$ which is less than $\alpha(<0.05)$

Table: 2

Testing of independence 'trade bodies identifying areas to equip women' and 'success of businesses'

\begin{tabular}{|c|c|c|c|c|c|c|c|}
\hline \multicolumn{2}{|c|}{ Trade bodies identifying areas to equip women for success * is business successful cross tabulation } \\
\multicolumn{2}{|c|}{} & $\begin{array}{c}\text { (Yes) I did } \\
\text { very hard } \\
\text { work }\end{array}$ & $\begin{array}{c}\text { (Yes) Staff/ } \\
\text { Trade body/ } / \\
\text { family } \\
\text { supported }\end{array}$ & $\begin{array}{c}\text { No policy for } \\
\text { women } \\
\text { entrepreneurs }\end{array}$ & $\begin{array}{c}\text { (No) Financial } \\
\text { problems/ less } \\
\text { investments }\end{array}$ & Total \\
\hline $\begin{array}{c}\text { Trade bodies } \\
\text { identifying } \\
\text { areas to equip } \\
\text { women for } \\
\text { success }\end{array}$ & Yes & Count & 45 & 41 & 9 & 7 & 102 \\
\hline \multicolumn{2}{|c|}{ Total } & Count & 45 & 29 & 15 & 9 & 98 \\
\hline
\end{tabular}




\section{Interpretation}

$\mathrm{H}_{\mathrm{o}}$ : Trade bodies are not identifying areas to equip women for business success.

$\mathrm{H}_{1}$ : Trade bodies are identifying areas to equip women for business success.

Pearson chi-square value $=3.729^{\mathrm{a}}$

$\mathrm{df}=3$

$\mathrm{p}=0.15$

Table: 3

Testing independence of 'Trade bodies encouraging women entrepreneurs for trademarks and patents' and 'Working for capacity building programmes'

\begin{tabular}{|c|c|c|c|c|c|c|c|}
\hline \multicolumn{8}{|c|}{$\begin{array}{c}\text { Trade bodies encouraging for trademark/patents * chambers organize capacity building } \\
\text { programs cross tabulation }\end{array}$} \\
\hline & & & \multicolumn{4}{|c|}{$\begin{array}{l}\text { Chambers organize capacity building } \\
\text { programs }\end{array}$} & \multirow{2}{*}{ Total } \\
\hline & & & $\begin{array}{l}\text { Within } 7 \\
\text { to } 30 \text { days }\end{array}$ & $\begin{array}{l}\text { Within } 90 \\
\text { to } 180 \text { days }\end{array}$ & $\begin{array}{c}\text { Within a } \\
\text { year }\end{array}$ & Never & \\
\hline \multirow{2}{*}{$\begin{array}{l}\text { Trade bodies } \\
\text { encouraging for } \\
\text { trademark/patents }\end{array}$} & Not helpful & Count & 25 & 20 & 2 & 27 & 74 \\
\hline & $\begin{array}{c}\text { Organize } \\
\text { seminars/ direct } \\
\text { assistance }\end{array}$ & Count & 69 & 30 & 3 & 24 & 126 \\
\hline \multicolumn{3}{|c|}{ Total } & 94 & 50 & 5 & 51 & 200 \\
\hline
\end{tabular}

\section{Interpretation}

$\mathrm{H}_{\mathrm{o}}$ : Trade bodies are not encouraging women entrepreneurs for trademarks and patents and impacts on capacity building of women entrepreneurs.

$\mathrm{H}_{1}$ : Trade bodies encouraging women entrepreneurs for trademarks and patents and effects on capacity building of women entrepreneurs.

Pearson chi-square value $=10.138^{\mathrm{a}}$

$\mathrm{df}=3$

$\mathrm{p}=0.0075$ 
Table: 4

Testing independence of 'education' and 'reason of starting work'

\begin{tabular}{|c|c|c|c|c|c|c|}
\hline \multicolumn{7}{|c|}{ Education * Reason of starting work cross tabulation } \\
\hline & & & \multicolumn{3}{|c|}{ Reason of starting work } & \multirow[b]{2}{*}{ Total } \\
\hline & & & $\begin{array}{c}\text { To increase } \\
\text { income of the } \\
\text { house/ make } \\
\text { life comfortable }\end{array}$ & $\begin{array}{c}\text { For children } \\
\text { education/ } \\
\text { unexpected } \\
\text { necessity }\end{array}$ & $\begin{array}{c}\text { For } \\
\text { ownership/ } \\
\text { utilize } \\
\text { education }\end{array}$ & \\
\hline \multirow{4}{*}{ Education } & Matriculation & Count & 13 & 0 & 3 & 16 \\
\hline & Intermediate & Count & 19 & 3 & 3 & 25 \\
\hline & Graduate & Count & 65 & 10 & 26 & 101 \\
\hline & Masters & Count & 26 & 7 & 25 & 58 \\
\hline \multicolumn{3}{|c|}{ Total } & 123 & 20 & 57 & 200 \\
\hline
\end{tabular}

\section{Interpretation}

$\mathrm{H}_{\mathrm{o}}$ : Women are educated due to the reason start working.

$\mathrm{H}_{1}$ : Women education is not the reason of starting work.

Pearson chi-square value $=14.106^{\mathrm{a}}$

$\mathrm{df}=6$

$\mathrm{p}=0.014$

Table: 5

Testing if independence of 'rising women entrepreneurship' and 'lower wages at work'

\begin{tabular}{|c|c|c|c|c|c|c|}
\hline \multicolumn{7}{|c|}{$\begin{array}{l}\text { Rising women entrepreneurship is a result of injustice in labour wages * reason of work cross } \\
\text { tabulation }\end{array}$} \\
\hline & & & \multicolumn{3}{|c|}{ Reason of starting work } & \multirow[t]{2}{*}{ Total } \\
\hline & & & $\begin{array}{c}\text { To increase income of } \\
\text { the house/make life } \\
\text { comfortable }\end{array}$ & $\begin{array}{c}\text { For children } \\
\text { education/un- } \\
\text { expected } \\
\text { necessity }\end{array}$ & $\begin{array}{c}\text { For own expenses/ } \\
\text { ownership/ } \\
\text { utilize education }\end{array}$ & \\
\hline \multirow{2}{*}{$\begin{array}{c}\text { Rising women } \\
\text { entrepreneurship } \\
\text { is a result of } \\
\text { injustice in labour } \\
\text { wages }\end{array}$} & Yes & Count & 113 & 14 & 49 & 176 \\
\hline & No & Count & 10 & 6 & 8 & 24 \\
\hline \multicolumn{3}{|l|}{ Total } & 123 & 20 & 57 & 200 \\
\hline
\end{tabular}




\section{Interpretation}

$\mathrm{H}_{\mathrm{o}}$ : Rising women entrepreneurship is not due to lower wages.

$\mathrm{H}_{1}$ : Rising women entrepreneurship is due to lower wages.

Pearson chi-square value $=8.104^{\mathrm{a}}$

$\mathrm{df}=2$

$\mathrm{P}=0.0085$

\section{Test 6}

Testing independence of 'First experience of work' and 'Work as an employee'

\begin{tabular}{|c|c|c|c|c|c|c|c|}
\hline \multicolumn{8}{|c|}{$\begin{array}{c}\text { Is this your first experience * did you work as an employee before starting business cross } \\
\text { tabulation }\end{array}$} \\
\hline & & & \multicolumn{4}{|c|}{ Did you work as an employee before starting business } & \multirow[b]{2}{*}{ Total } \\
\hline & & & $\begin{array}{l}\text { (Yes) } 1 \text { to } \\
6 \text { years }\end{array}$ & $\begin{array}{c}\text { (Yes) } 7 \\
\text { to } 10 \\
\text { years }\end{array}$ & $\begin{array}{c}\text { (No) } \\
\text { Insufficient } \\
\text { wages }\end{array}$ & $\begin{array}{l}\text { (No) Did not want to } \\
\text { work as subordinate/ } \\
\text { in stereotype jobs }\end{array}$ & \\
\hline \multirow{2}{*}{$\begin{array}{l}\text { Is this your first } \\
\text { experience }\end{array}$} & Yes & Count & 9 & 4 & 84 & 60 & 157 \\
\hline & No & Count & 25 & 10 & 6 & 2 & 43 \\
\hline \multicolumn{3}{|c|}{ Total } & 34 & 14 & 90 & 62 & 200 \\
\hline
\end{tabular}

\section{Interpretation}

$\mathrm{H}_{\mathrm{o}}$ : First experience as an employee then started work as an entrepreneur.

$\mathrm{H}_{1}$ : First experience of work as an entrepreneur to avoid working as employee.

Pearson chi-square value is $99.21^{\mathrm{a}}$

$\mathrm{df}=3$

$\mathrm{p}=0$

\section{Results and Discussions}

The trade bodies have been formed to protect private sector from wrong policies of the government and any new world order affected local businesses. At the same time chambers and association also play a critical role in promoting and protecting the rights and an individual businessperson. The changing business environment has increased the importance of women, especially due to their dominance in education and demand for economy of skilled labor. The trade bodies are aimed at promoting business activities of 
both men and women. Historically, men are dominant in the economic arena and trade bodies give priority to their male members. But this approach has been changed new due to multiple reasons and increased membership of women entrepreneurs. The rising induction of women entrepreneurs not only compelled the trade association to give attention but it also resulted in creation of separate women chambers. The finding of this research work revealed that though trade bodies were promoting the business activities of women entrepreneurs yet unable to resolve their financial matters. The dynamics of business have been changed over the period and women entrepreneurs require advanced skill and techniques to operate their businesses. It is identified that the trade bodies are so far not much helpful in capacity building of those business women.

In table 1 , the identified Pearson chi-square value is $25.310 \mathrm{a}$ with 3 degree of freedom. The tabulated P-value is 0 which is less than $\alpha(<0.05)$ therefore null hypothesis rejected. The cross tabulation and chi-square results show that there is association between women chambers promoting women in private sector and success of business. Therefore, it concluded that women chambers are promoting women in private sectors through organizing business meetings, conferences, exhibitions, seminars and workshops and running successful business. Its P-value shows that there is strong relationship between these two variables. Similarly, in table 2 the Pearson chi-square value is $3.729 \mathrm{a}$ with 3 degree of freedom. The tabulated P-value is 0.15 which is more than $\alpha(>0.05)$ therefore null hypothesis accepted. The cross tabulation and chi-square results show that there is no association between trade bodies identifying areas to equip women and business success. Therefore, it concluded that in this segment there were different responses received in terms of success of business. In this table there are two groups who believed that their businesses were successful due to their hard work. Another group attributed their success to support from family and friends. Its P-value shows that trade bodies are not identifying areas to equip women for business success. Therefore, the trade bodies required to expand the scope of working and acquire expertise of international standards to equip women with the advanced techniques for running their businesses on modern lines. However, the analysis of the two tables concluded that the P-value showed strong relationships between two categorical variables including women chambers promoting women in private sector as businesses are successful and trade bodies are encouraging women entrepreneurs for trademarks/patent through capacity building programmes. These two tested variables have dependency over successful businesses. Therefore, the hypothesis 'Role of trade associations is helpful in promoting business of women' is approved according to statistical significance in variables magnitude. In table 4, the Pearson chi-square value is $10.138^{\mathrm{a}}$ with 3 degree of freedom. The tabulated P-value is 0.0075 which is less than $\alpha(<0.05)$ therefore null hypothesis rejected. The cross tabulation and chi-square results show that there is association between trade bodies encouraging women entrepreneurship for trademarks and patents and working for capacity building programmes. Therefore, it concluded that trade bodies are encouraging 
women towards trademark and patents through organizing different capacity building programmes for women entrepreneurs. Its P-value shows that there is significant relationship between these variables.

The research work also identified that wages have strong relation with the cost of doing business. In case wages increase in labor market the cost of a manufacturing unit increases and it becomes uncompetitive in the international markets. Therefore, for the long time the wages of the laborers were not increased as per to the inflationary pressures. The literature review pointed out that women were mostly engaged in non-skilled works in the past, which attract lower wages as compared to skilled work. In the recent times the dominance of female in education prompted them to acquire professionalism in sectors of the economy. This has changed the entire concept and women moved to entrepreneurship. It is observed that women are working in mainly in textile factories, especially in garments and finished products related activities. In these business activities, though, hard work is not required but the wages are very low. The women are breaking the barriers and attaining education and advanced skills and moving towards entrepreneurship. Though this is in the early stage but changing composition of men and women business activities, one can assumes the women will be able to accelerate their presence in future. The dominance in education was also due to lower wages of women in economic activities. The research finds that women who started their own businesses are well-educated.

The analysis of table 4 shows the Pearson chi-square value is 14.106a with 6 degree of freedom. The tabulated P-value is 0.014 which is less than $\alpha(<0.05)$ therefore null hypothesis rejected. The cross tabulation and chi-square results show that there is significant association between education and reason of staring work. Therefore, it concluded according to table results that all group of qualification had affirmed that they joined the work for earning to support their household economies. Its P-value shows that there is relationship between variables. Similarly, in table 5 the Pearson chi-square value is 8.104a with 2 degree of freedom. The tabulated P-value is 0.0085 which is less than $\alpha$ $(<0.05)$ therefore null hypothesis rejected. The cross tabulation and chi-square results show that there is significant association between rising women entrepreneurship and lower wages at work. The large number of respondents believed that rising women entrepreneurship is due to injustice in labour wages. Its P-value shows that there is strong association between variable. It is concluded that the P-value determined powerful association between all three categorical variables including women education, first experience of work as an entrepreneur and rising women entrepreneurship have strong dependency over factors such as reasoning of work, want to work as an entrepreneur in a way to avoid working as subordinate or under lower wages. These economic changes are considering women to get into entrepreneurship instead of working as employee. Therefore, the hypothesis 'The changing economic conditions lead women towards 
entrepreneurship' is approved according to statistical significance in variables magnitude. In table 6, the Pearson chi-square value is $99.21^{\text {a }}$ with 3 degree of freedom. The tabulated P-value is 0 which is less than $\alpha(<0.05)$ therefore null hypothesis rejected. The cross tabulation and chi-square results show that there is significant association between first experience of work and work as an employee. Therefore, it concluded that most of women entrepreneurs never worked as an employee due to lower wages and were not interested in stereotype jobs due to the reason started own work. Its P-value shows that there is strong relationship between variables.

\section{Conclusions}

The thorough research of this study concluded that women entrepreneurs need unity to show their presence in mainstream economic activities. This unity should be regardless of their type of business, size of business, sectors of economy or irrespective of political interference. This networking should be based on gender equality and equity which will be helpful in removing all irritants. Trade bodies can be helpful in raising their voices as they are providing platform for representations yet such opportunity was not explored in true sense so far. There is need to develop a database of working women at government as well as private sector level to identify women and their economic activities. This data should be used for identifying the potential of existing expertise of businesswomen as well as creating room for new entrepreneurs.

\section{Recommendations}

Women should be encouraged to participate in economic activities at all levels. Policies and laws should be evolved in this way that women belonging to rural and urban areas should come forward.

$>$ Remove irritants in obtaining loans. The loan extending financial institutions should have clear policy without hidden charges on their advances.

$>$ The minimum loan size for women entrepreneurs should be one million rupees considering the changing demand and cost of doing business.

$>$ Women should be discouraged to import raw material especially those which are already available in the local markets.

$>$ Establish centers at government as well as private sector associations for creating linkages between domestic women entrepreneurs with their foreign business partners. 


\section{References}

Agalgatti, Bhooshan B. (2008). Labour Welfare and Industrial Hygiene, Nirali Prakashan, Pune, pp. 270-271

Alam, Kazmi (2012, July 18). Revitalization Needed: Women Chamber Gathering Dust Since Inception. The Express Tribune. Retrieved from http://www.tribune.com.pk on January 12, 2013.

Bahramitash, R. \& Espahani, H. (2016). Political and Socio-Economic Change in the Middle East and North Africa: Gender Perspectives and Survival Strategies, Palgrave Macmillan, New York, p.(n).

Banaszak, A. L. (2006). The US Women's Movement in Global Perspective, Rowman \& Littlefield, INC., United States of America, pp.133-134

Bennett, J. Robert (2011). Local Business Voice: The History of Chambers of Commerce in Britain, Ireland, and Revolutionary America, 1760-2011, Oxford University Press, United States, pp. 13-14

Bhargava, R., \& .A .Bagchi K Sudarshan R. (2007). Multiculturalism, Liberalism, and Democracy, Oxford, India, p.392.

Busquets, Carlos F. B. (2006). The Role of Trade Barriers in SME Internationalization, OECD Trade Policy Working Paper No 4, p.4.

Commonwealth Secretariat (2002). Commonwealth Businesswomen Trade Matters, Best Practice \& Success Stories: Commonwealth Secretariat, European Union, p.34.

DGTO. (2013). Trade Act 2013, Directorate General of Trade Organization, Pakistan, pp. $40-41$

Dr. Vural, ErenIpek (Ed) (2011). Converging Europe: Transformation of Social Policy in the Enlarged European Union and Turkey, Ashgate, England, p.22.

Duiker, J. W. \& Spielvogel J. J. (2010). World History, Clark Baxter and Suzanne Jeans, p.853.

Ember, R. C. \& Ember, M. (Ed.) (2003). Encyclopedia of Sex and Gender: Men and Women in the World's Cultures, Kulwer Academic/Plenum, New York, p.360. 
Economist Publication (2007). Pakistan \& Gulf Economist, Economist Publications, London, vol.26-27, p.47.

Forestell M. N. \& Moynagh, M. (Ed.) (2014). Documenting First Wave Feminisms: Volume II Canada National and transnational contexts, University of Toronto Press, p. xvii.

FPCCI. (2014). FPCCI Annual Report, Federation of Pakistan Chambers of Commerce and Industry Publication, Karachi p.26.

Galindo, Miguel A. \& Riberio, Domingo (2012). Women's Entrepreneurship and Economics: New Perspectives Practices, and Policies, Springer, London, p. 146.

Goodwin, J. \& Jasper, M. J. (Ed.) (2009). The Social Movements Reader: Cases and Concepts, Blackwell, Utopia, p.377.

Grob, G. N. \& Billias, A.G. (Ed.) (1992). Interpretation of American History: Patterns and Perspectives, Simon \& Schuster Inc, United States of America, p.81.

Guy, Parrott (2008). Barriers to Development and Progression of Women Entrepreneurs in Pakistan, Journal of Entrepreneurship, Vol. 17, Sage Publications, p.70.

Hagan, O., Rivchun, C., Sexton L. \& Donald (1998). Women-owned Businesses, Praeger, USA, p.26.

International Finance Corporation (2004). Women Entrepreneurs in the Middle East and North Africa, The Center of Arab Women for Training and Research \& the IFC Gender Entrepreneurship Market, USA, p.8.

Investopedia (2014). http://www.investopedia.com/terms/c/chamber-of-commerce.asp, retrieved on January 20, 2014.

Kahle, Anita (2005). First Wave of Feminism in Politics and Literature, GRIN Verlag, Germany, p.4.

Lodhi, MA. (2015). Final List of Candidates, FPCCI Elections for the Year 2015, Federation of Pakistan Chambers and Commerce and Industry (FPCCI), Karachi, Pakistan, p.4. 
Makombe, Iddi A. M. (2006). Women Entrepreneurship Development \& Empowerment in Tanzania: The Case of SIDO/UNIDO-Supported Women Micro-Enterprises in The Food Processing Sector, University of South Africa, South Africa, pp.70-177

Marsh, Nicky (2008). Money, Speculation and Finance in Contemporary British Fiction, Continuum, UK, pp.133-134.

McGuire, P. \& McQuarie, D. (1994). From the Left Bank to the Mainstream: Historical Debates and Contemporary Research in Marxist Sociology, General Hall Inc, USA, pp. $57-60$

Ministry of Commerce (2013). Trade Organization Rule, Ministry of Commerce publication, Pakistan, p.2.

Mumba, Daniel (2014). Empowering Women Enterprises in Africa: Investigating Information Access \& Use of Information \& Communication Technologies by Women-Owned Enterprises in Zambia, The University of Western Ontario, London, p.195.

Nadgrodkiewicz, A. (2011). Empowering Women Entrepreneurs: The Impact of the 2006 Trade Organization Ordinance in Pakistan, Center for International Private Enterprise (CIPE), Washington D.C, pp.2-3.

Nirjar, Abhishek (2011). Entrepreneurship Development, Word Press, India, p.210.

OECD (1998). Women Entrepreneurs in Small and Medium Enterprises, OECD Publication, France, p.51.

OECD (2012).Competitiveness and Private Sector Development Women in Business: Policies to Support Women's Entrepreneurship Development in the MENA Region, OECD Publication, p.56.

Pushkareva, Natalia (1997). Women in Russian History: From the tenth to the Twentieth Century, M. E Sharp. Inc, New York, pp.7-8

Raghavan, S. N. (1995). Regional Economic Cooperation Among SAARC Countries, Allied Publisher Limited, New Delhi, p. XI.

Rani, Lalitha D. (1996). Women Entrepreneurs, A.P.H Publishing Corporation, New Delhi, p.6. 
Richard, R. R. (2008). Riding the waves: A trans-generational Approach to the Feminist Movement in the United States, Thesis of Loyola University Chicago, USA, p.39.

Smith, Nair (2013). Assessing Customer Satisfaction and Brand Awareness of Branded Bread, IOSR Journal of Business and Management Publication, India, p.18.

Singla, R.K. (2009-10). Business Organizations, Neekunj print process, Delhi, pp. 178185

Sharma, Yogita (2013). Women Entrepreneurs in India, IOSR Journal of Business and Management Publication, vol.15:3, pp.9-14.

Shukla, A. B. (2006). Women on Women: A Feminist Study, Sarup \& Sons, New Delhi, pp.7-8

The Express Tribune (2010, December 10). FPCCI Invites Application. The Express Tribune, retrieved from: http://www.tribune.com.pk on January 5, 2016.

Stange, Oyster and Sloan (Ed.) (2011). Encyclopedia of Women in Today's World, SAGE, California, p.210.

The Express Tribune (2014, December 5). Pakistani Women Earn 38.5\% Less than Men: Report, The Express Tribune, retrieved from: http://tribune.com.pk on January 2, 2015.

Tandon, Neeru (2008). Feminism: A Paradigm Shift, Atlantic, New Delhi, p.3.

Tariq, Waleed (2015, October 12). The Importance of Karachi. Business Recorder. retrieved from: http://www.tribune.com.pk on May 31, 2013.

UNDP. (2003). Women and Chambers of Commerce: Case Studies from the Gulf, UNDP Publication, Washington D.C, p.6.

US Department of Health (n.d.). Education and Welfare (1970). Automation and Women Workers, Office of Education, USA, p.3.

Verdon, Nicola (2002). Rural women workers in $19^{\text {th }}$-Century England: Gender, Work and Wages, The Boydell Press, UK \& USA, p.9.

World Bank (2012). Are Pakistan's Women Entrepreneurs Being Served by the Microfinance Sector? World Bank, Washington DC, p.5. 
Wube, Mulugeta C. (2010). Factors Affecting The Performance of Women Entrepreneurs in Micro \& Small Enterprises, Bahir Dar University, Ethiopia, pp.59-63

Shazia Sharafat is Ph.D. Scholar in the Centre of Excellence for Women's Studies, University of Karachi.

Dr. Nasreen Aslam Shah is Meritorious Professor: Chairperson in the Department of Social Work and Director, Centre of Excellence for Women's Studies, University of Karachi. 